\title{
La Rábita de Guardamar: un proyecto de musealización
}

\author{
Rafael Azuar Ruíz* \\ Marga Borrego Colomer \\ Rosa Saranova Zozaya
}

La presente comunicación es una síntesis del estudio museológico sobre el yacimiento de la Rábita Califal de las Dunas de Guardamar del Segura, encargado por la Consellería de Cultura del País Valenciano y realizado por un equipo interdisciplinar I.

El objetivo de dicho estudio fue extraer del yacimiento y su entorno natural un óptimo aprovechamiento, ajustado a sus posibilidades reales y en concordancia con otras experiencias similares desarrolladas en Europa. Por tanto, se inició el estudio analizando la situación material y jurídica en la que se encontraba el área arqueológica y su entorno medio-ambiental, con objeto de definir la figura patrimonial que mejor se adaptase a su realidad y a su potencialidad cultural.

Tras individualizar y resaltar la relevancia y la singularidad de los componentes fundamentales del futuro Parque, el estudio señala un eje, una línea programática a seguir en la elaboración de los proyectos y actuaciones que se lleven a cabo en su puesta en marcha, mediante la definición de los objetivos y funciones inherentes a un parque arqueológico.

El estudio igualmente significó las normas que debían animar la musealización del Parque, subrayando los valores conceptuales de las diferentes unidades de representación que lo caracterizan y distinguen. De esta forma, se pretendía alcanzar una adecuada legibilidad de su realidad, rentabilizando social y culturalmente su creación.

\section{CONCEPCIÓN GENERAL DEL YACI- MIENTO}

\section{I.I SINGULARIDAD DEL YACIMIENTO}

La actuación arqueológica llevada a cabo en las Dunas de Guardamar junto a la desembocadura del río Segura, como es de sobra conocido, ha sacado a la luz un complejo arquitectónico de época islámica. Las ruinas exhumadas conforman una amplia y variada tipología de edificios -mezquita, oratorios y habitaciones- íntimamente relacionados con el carácter cúltico del conjunto, una rábita del siglo $X$. Las diversas estructuras se organizan espacialmente en tres líneas de construcciones configurando una planta semejante al casco de una nave cuya proa apunta a levante. Los tres cuerpos edilicios se vertebran a través de dos calles que vienen a converger en un amplio patio, donde se abre la única puerta conocida de acceso al recinto de la Rábita.

Nos hallamos, por consiguiente, ante la materialización de una institución religiosa islámica de carácter cenobítico: una rábita, destinada a la defensa y aculturación de un territorio. El período de vida de nuestra Rábita fue exiguo, algo más de cien años, transcurridos desde las postrimerías del siglo IX hasta el ecuador del siglo XI.

La peculiaridad de este conjunto se refleja en su relevancia histórica. No en vano, la Rábita Califal de las Dunas de Guardamar es uno de los ejemplos más antiguos de este tipo de institución religiosa conservado en todo el Mediterráneo Occidental y, por el momento, la única descubierta en España. 
Además de su indudable valor científico e histórico la Rábita posee un evidente carácter monumental debido al buen estado de conservación de su arquitectura. A los restos ya excavados, que en ocasiones superan los dos metros de altura, se debe añadir un potencial monumental oculto, pero detectado por diversos análisis electrofísicos. Hasta el momento el yacimiento ha proporcionado una gran mezquita de dos naves, construida a partir de una "qibla" de "musal.la", sencillamente decorada; más de veinte celdas-oratorio, semejantes en planta y diversas en cuanto a las soluciones constructivas adoptadas y, por último, seis pequeñas estancias.

No debemos olvidar el gran interés que suscita la inestimable documentación parietal que aparece en varios de los edificios del conjunto. Nos referimos en concreto a los diversos testimonios epigráficos, la pintura mural y las varias técnicas constructivas con las que se levantan y decoran las diferentes estructuras de la Rábita.

\section{I.2.SITUACIÓN LEGAL DEL YACIMIENTO}

Desde la aparición del monumento, dada su singularidad, su importancia histórico-cultural y su excelente estado de conservación, se hizo necesario conferirle un tratamiento de intervención dirigido a protegerlo y difundirlo de manera adecuada.

Afortunadamente, el yacimiento se encuentra situado en un terreno de propiedad pública, lo cual evita la utilización de figuras como la expropiación, que generalmente dificultan y encarecen, cuando no imposibilitan, el acceso de la sociedad a un bien cultural que, de facto, le pertenece. Y, por añadidura, la Rábita se halla inmersa en un paraje natural, las Dunas de Guardamar del Segura, que goza de protección y de un tradicional favor popular.

Esta privilegiada situación patrimonial unida a la importancia científica y a la ideal ubicación del monumento instaron, previa solicitud de la Consellería de Cultura de la Generalidad Valenciana, a que el Ministerio de Cultura en 1987 incluyera el yacimiento en el "Plan Experimental de Parques Arqueológicos Nacionales". En dicho proyecto se tiende a desarrollar una actuación integral sobre aquellas zonas arqueológicas de relevancia científica, que mantienen un buen estado de conservación, son accesibles a un elevado número de visitantes y, en definitiva, cuentan con un óptimo rendimiento social. Asímismo, para la elección de los sitios arqueológicos, que participarían inicialmente de dicho plan, se valoró el paisaje natural en el que se hallan imbricados los restos arqueológicos. 2

El 2 I de junio de 1989 la Consellería de Cultura, Educación y Ciencia de la Generalidad Valenciana lo declarará Bien de Interés Cultural con la categoría de zona arqueológica. Asímismo, el 27 de julio del año 1990 el Ministerio de Cultura considera el yacimiento "La Rábita Califal de las Dunas" y su área de influencia Bien de Interés Cultural con dicha categoría.

Con la declaración de "zona arqueológica" quedaban cubiertas, desde un punto de vista legal, las necesidades de protección y conservación del monumento. Sin embargo, dicha figura era insuficiente a la hora de abordar un principio básico, el rendimiento cultural a través del uso público. De ahí que fuera imprescindible adoptar una nueva figura, la de "Parque Arqueológico", capaz de conjugar las funciones de conservación, restauración y dinamización del monumento y de su entorno.

En 199| se firmará un convenio a tres bandas Ministerio de Cultura, Generalidad Valenciana y Ayuntamiento de Guardamar del Segura- orientado a la institucionalización y puesta en marcha del "Parque Arqueológico de la Rábita Califal de Guardamar".

\section{I.3. CONDICIONES MATERIALES DEL YACI- MIENTO.}

Lamentablemente, las ruinas de la zona arqueológica se han visto sometidas desde su excavación a una progresiva degradación debida a la acción antrópica y, sobre todo, a diversos agentes naturales. No debemos olvidar que unos restos enterrados durante más de mil años bajo la arena, en unas condiciones ambientales determinadas, sufren con su exhumación una brusca agresión. A la erosión de los agentes naturales -variación térmica, viento, lluvias, etc...- que afectan a todo monumento, en nuestro caso concreto debemos yuxtaponer la virulencia de los mismos y la delicada morfología de las construcciones y del medio en que se levantan. 
Los edificios de la Rábita se asientan directamente sobre una antigua duna de arena; carentes de cimentación, se edifican en la mayor parte del conjunto con técnicas constructivas y de acabado de escasa consistencia. La mampostería utilizada está levemente trabada con un mortero de barro muy arenoso, que se emplea asímismo en la fabricación de los tapiales. Si frágiles son las soluciones constructivas adoptadas, no lo son menos sus técnicas de acabado, pues se reducen a un enlucido de cal cuya protección requeriría una intervención inmediata, dado que soporta una documentación epigráfica y decorativa de inestimable valor.

Con el fin de paliar la progresiva degradación de los restos arqueológicos exhumados se ha llevado a cabo una primera fase de consolidación provisional, en espera de que se adopten las soluciones de protección integral. El soporte infraestructural y el componente social, imprescindibles en el desarrollo del Parque, presentan una situación previa más alentadora.

La infraestructura con la que debe contar el Parque es compleja y distinta. Por una parte, precisa de un equipamiento intrínseco que se desarrollará con mayor detalle en otros apartados del estudio. Sin embargo, cabe anunciar que la zona protegida posee ya algunos elementos infraestructurales reciclables, tales como vías de acceso al Parque, zona de aparcamiento y una ruta que rodea toda el área.

Por otra parte, el Parque tiene garantizada una buena comunicación con el exterior al hallarse en un centro urbano costero, Guardamar del Segura, enlazado con otros centros importantes a través de una sólida red viaria: el Parque Arqueológico está situado, a tres kilómetros de la autovía AlicanteCartagena, en la carretera nacional que une ambas ciudades y que conecta los municipios turísticos costeros. De otro lado, dista treinta kilómetros de la autopista A-7 y, tan sólo, veinte del Aeropuerto de Alicante. Asímismo, la ciudad le proporciona una serie de servicios que, de hallarse aislado, el propio Parque debería asumir.

La Rábita se emplaza en un territorio de amplio potencial humano. No sólo cuenta con varios centros urbanos que rondan o superan los trescientos mil habitantes -Alicante, Elche, Cartagena y Murciay con numerosos municipios cercanos cuya pobla- ción oscila entre los cincuenta mil y los cien mil habitantes -Elda, Orihuela, Crevillente, etc...-, lo que le asegura una importante afluencia de público, mediante visitas individuales u organizadas; sino que, su ubicación en el eje turístico de centros de población estacional -Santa Pola, Torrevieja, La Manga, etc...- de larga tradición, le garantiza un elevado rendimiento social y de autofinanciación.

En buena lógica, la comunicación del Parque con los diversos colectivos humanos deberá ser canalizada mediante una acción didáctica que garantice su disfrute y una óptima comprensión de los diferentes elementos culturales.

\section{EL PROGRAMA -OBJETIVOS Y FUN- CIONES- DEL PARQUE.}

El programa científico del Parque Arqueológico se construye a partir de la definición de los objetivos que éste persigue y de las funciones que debe desarrollar en la consecución de los mismos. Dicho programa será el soporte ideológico del Parque $y$, por ende, su configurador.

El objetivo prioritario del Parque Arqueológico de la Rábita de Guardamar será poner en relación el bien arqueológico y su entorno con el colectivo social, para su adecuado conocimiento y óptimo disfrute. Por lo tanto, a este principio programático regulador y configurador del Parque deberán someterse, lógicamente, el resto de los objetivos y funciones inherentes a su contenido y definición. El Parque se convierte, de esta forma, en un instrumento de comunicación entre la sociedad y su pasado histórico.

Para lograr establecer dicha comunicación el Parque debe entenderse como un gran Museo cuyas instalaciones son su propio contexto espacial. A diferencia de esta tradicional institución el Parque presenta y expone los bienes culturales que lo integran -objetos muebles e inmuebles, ecosistema, etc...- en su medio físico original. Junto a la función educativa el Parque Arqueológico, a través de una correcta planificación didáctica, potenciará el sentido lúdico de la visita museal.

Por consiguiente, si nos hallamos ante una nueva figura museográfica, las funciones y objetivos que 
ésta debe cumplir serán parangonables a las de cualquier museo: investigación, conservación y difusión. Ahora bien, la especificidad del Parque influirá considerablemente en la concepción, valoración y desarrollo de las mismas.

\section{I. INVESTIGACIÓN.}

En el museo arqueológico tradicional los objetos se exponen descontextualizados, fuera de su ambiente original; llegan hasta las vitrinas a través de diversos medios: donación, compra, excavaciones..., dependiendo siempre de recursos externos. Por el contrario, el Parque Arqueológico es en sí mismo el objeto museable y el generador de su propia exposición, presentándola inmersa dentro de su contexto espacial.

Toda experiencia museística se basa en una profunda investigación, por ello, para restituir de forma adecuada el ambiente original del principal objeto museable del Parque, la Rábita Califal -su plasmación material, su cotidianidad, su entorno natural y su relación con el territorio-, es preciso desarrollar una exhaustiva y correcta labor investigadora de carácter interdisciplinar.

La investigación en este campo concreto no puede entenderse ni llevarse a efecto sin la adecuada aplicación de unas técnicas específicas previas: prospección, excavación y documentación arqueológica, cuya finalidad es la recogida sistemática de los datos. La investigación en el Parque Arqueológico de la Rábita, lógicamente, no se limitará a esta primera fase. Si bien, el acopio y la catalogación de los bienes constitutivos del Parque es imprescindible y paso obligado para alcanzar un estado más profundo en el análisis científico del hecho histórico y del medio ambiente.

Únicamente, tras un riguroso análisis científico de los elementos que definen el Parque y de las relaciones existentes entre ellos, se podrá comunicar la realidad histórica materializada en la Rábita y en su entorno medioambiental. Ahora bien, esta comunicación sería inviable sin una correcta exposición de los mismos y sin una celosa salvaguarda de los restos arqueológicos y del paisaje en el que se imbrican.
Mediante la fiel restitución del bien cultural, la sociedad podrá comprender el significado de cada uno de sus elementos y, por lo tanto, se conseguirá su preservación y transmisión. Sin embargo, la naturaleza y diversidad de los componentes del Parque requiere la intervención de un equipo interdisciplinar, de científicos y profesionales, que contribuya, con sus conocimientos y experiencia, a la consecución de este objetivo fundamental.

El Parque deberá convertirse, por lo tanto, en un centro de investigación y formación en el que confluyan especialistas en las diversas disciplinas que se pueden estudiar en él. En la relación del Parque con la comunidad científica se establecerá un fructífero intercambio: el primero pondrá su realidad material al alcance del experto análisis del especialista, a la par que éste lo enriquecerá al hacerlo progresar en su legibilidad, en su conservación, en su divulgación, etc... Pero, el Parque no sólo debe entenderse como un centro de investigación, en el que se aúnen los trabajos de reconocidos científicos, sino que deberá prestarse al estudio y a la formación de estudiantes e investigadores noveles.

La Rábita se nos presenta como el laboratorio idóneo para profundizar en el estudio del ecosistema de dunas litorales: evolución, mutaciones, etc...; y de la cultura islámica: sus períodos paleoislámico y califal, sus instituciones religiosas, su arquitectura, su cultura material y un sinfín de temas imposibles de enumerar. Asimismo, deberá ser campo de experimentación de diferentes técnicas y métodos de actuación arqueológica y de restauración. Por ejemplo, la diversidad de técnicas constructivas utilizadas en la Rábita, unido a su óptimo estado, la convierten en uno de los yacimientos privilegiados a la hora de ensayar diferentes técnicas rehabilitadoras que, a su vez, propiciarán su adecuada conservación.

\section{II.2. CONSERVACIÓN.}

Uno de los fundamentos sobre los que se construye el entramado material e ideológico del Parque Arqueológico es la protección de los diversos bienes culturales que lo integran. Este fundamento, caracterizador del Parque, se proyecta no sólo sobre el yacimiento y sus restos materiales, sino también sobre el medio físico y sus compo- 
nentes. Asímismo, la acción tutelar afectará tanto a los bienes exponibles como a los que, por diversas causas ya sean intrínsecas o extrínsecas al propio bien, no merezcan ser musealizables, puesto que la tarea de la conservación se ejercerá sobre todo el conjunto del Parque, independientemente de su valor expositivo. Uno de los objetivos inherentes al concepto de Parque Arqueológico es, por consiguiente, la defensa y conservación de su legado patrimonial.

Sin embargo, dicha finalidad y objetivo parece, en principio, entrar en contradicción con la idea de la accesibilidad del bien cultural. A nadie se le escapa que el uso público indiscriminado de un bien puede deteriorarlo seriamente e incluso destruirlo; aunque, por el contrario, es también obvio que un disfrute y una utilización planificada del mismo contribuye a su mantenimiento y evita su desaparición. De esta forma, el Parque Arqueológico deberá conjugar ambos objetivos y finalidades, la conservación y el uso del bien, para que el principio rector del mismo, poner en comunicación el ente social con el bien arqueológico y su entorno natural, sea no sólo alcanzado de forma satisfactoria sino que mantenga su vigencia a través del tiempo.

El Parque Arqueológico tiene que contar con los medios necesarios, materiales y humanos, para llevar adelante una conservación efectiva de sus componentes que, dada su distinta naturaleza, precisan de variadas medidas de protección aplicables a tenor de numerosos factores como el tipo de elemento a tratar, su fragilidad, su estado de conservación, el estadio de consolidación en el que se encuentre, etc...

\section{II.2.I. MEDIO NATURAL.}

El yacimiento de la Rábita se encuentra inmerso dentro de un ecosistema dunar cuyas características han sido analizadas ampliamente en una obra de conjunto que establece, entre otras cuestiones, una serie de medidas protectoras para este tipo de paisajes que, lógicamente, afectarían al área del Parque. ${ }^{3}$

Huelga repetir la importancia que el medio natural tiene en la configuración del Parque Arqueológico, por lo tanto, para la conservación del actual paisaje, dunas y pinadas, el Parque Arqueológico deberá contar con el asesoramiento de expertos que analicen, entre otras cuestiones, la repercusión que sobre el medio natural ha tenido y tendrá la actuación arqueológica, formas de paliarla o aminorarla, tipos de protección, etc... Asímismo, el cuidado y repoblación del Parque quedará en manos de personal competente en la materia.

\section{II.2.2. RESTOS ARQUEOLÓGICOS.}

En el yacimiento arqueológico se reservarán con vistas al futuro zonas de estricta protección, no excavables. Esta medida tiene como objeto preservar parte de los restos arqueológicos para futuras investigaciones, ya que el devenir y los avances científicos pueden proporcionar técnicas de excavación y análisis hoy desconocidas, pero que podrían solucionar con su aplicación enigmas que el estado de la investigación actual no permite ni resolver, ni tan siquiera plantear.

Por otra parte, la protección de los restos exhumados se abordará mediante un programa de conservación que afectará al material inmueble, mueble y paleoambiental y que se realizará, dependiendo de la naturaleza y estado de conservación del bien, en varias fases sucesivas que denominamos: protección, consolidación y restauración.

\section{III.3. DIFUSIÓN.}

Decíamos, al iniciar este apartado sobre los objetivos a perseguir por un Parque Arqueológico y, más en concreto, por el de la Rábita Califal de las Dunas de Guardamar, que el principio rector, que debe animar todas las actuaciones del mismo, es el de comunicar el bien arqueológico y su entorno con el colectivo social. La difusión del Parque Arqueológico en su conjunto es, por consiguiente, el objetivo prioritario al que, de alguna manera, parecen supeditarse el resto de los objetivos y funciones. No obstante, para divulgar la realidad material del Parque debe existir, naturalmente, un conocimiento del mismo, una investigación anterior que permita su explicación y una conservación adecuada que facilite su trasmisión. De esta forma, investigación, conservación y difusión se presentan relacionadas, dependientes e inseparables. 
Toda divulgación pone en interacción una serie compleja de factores que se concretizan en: el objeto a difundir, el receptor de la comunicación y el medio o código de trasmisión.

El objeto a divulgar es el conjunto del Parque Arqueológico integrado tanto por su realidad material -restos arqueológicos, medio natural, paleoambiente, etc...- como por su realidad investigadora resultados de los estudios desarrollados en torno a sus elementos y componentes-. De ahí que, nos hallemos ante un objeto de divulgación complejo y distinto. El receptor de toda esta información tampoco es homogéneo, muy al contrario, se presenta tan variado y singular como la propia sociedad de la que forma parte. De esta manera, los códigos de trasmisión serán diversos, ajustados a la complejidad que supone poner en relación dos realidades también diversas, el objeto divulgativo y el receptor al que se dirige su conocimiento.

La divulgación y difusión del Parque Arqueológico la entendemos como: difusión interna, aquella que se realiza en el interior del propio Parque, y difusión externa, aquella que traspasa los límites del mismo. En la primera los diferentes componentes del Parque se muestran in situ, en su contexto; mientras que, en la segunda éstos transgreden su contextualidad, en un intento de llegar a un colectivo más amplio.

\section{II.3.I DIFUSIÓN INTERNA.}

La difusión interna se materializará a través de la exposición del propio Parque Arqueológico, donde el elemento social se comporta como el agente activo de la relación. Por consiguiente, la muestra de los diferentes componentes del Parque acogerá al público visitante, colmando, en la medida de lo posible, sus diversas expectativas. Para ello, se potenciará una acción didáctica y dinamizadora de la exposición de los restos arqueológicos y del entorno del Parque, con distintos niveles de conocimiento, adaptados a las exigencias del público.

El Parque, indiscutiblemente, deberá tener en cuenta la variedad de usuarios que a él se acerquen, ofertando, por ende, actividades de diferente contenido: área histórico-arqueológica, área de natura, área lúdica, etc... Estas actividades se canali- zan a través de itinerarios o recorridos temáticos. En el Parque de la Rábita se proyectarán distintos circuitos, en unos se incidirá en un aspecto concreto del mismo (arqueología, naturaleza, etc...), mientras que, en otros se tratará su diversidad.

Dentro del proyecto de divulgación se planificarán varias instalaciones museográficas temáticas de carácter fijo: exposición del monumento en sí, un museo de apoyo histórico-arqueológico, dos aulas de natura y el propio contexto ambiental del Parque. Estas instalaciones deben entenderse como una serie de códigos de divulgación que acerquen el conocimiento del conjunto del Parque al público en general. Por tanto, como transmisor de un conocimiento deberán pensarse en continuo cambio a tenor del avance en la investigación generada desde el propio Parque.

Una de las actuaciones que impulsará el Parque Arqueológico de Guardamar a través de su Centro de Investigación será la organización de simposios, encuentros, seminarios, etc..., con el objetivo de exponer sus avances científicos y metodológicos, conocer los trabajos de otros investigadores, estableciendo fructíferos intercambios. Los encuentros tendrán un carácter plural, además de la temática histórico-arqueológica, inherente al Parque de Guardamar, se abordarán cuestiones propias de la organización y gestión de los Parques, tales como su dinamización, medios de financiación, propuestas de musealización, etc...

\section{II.3.2 DIFUSIÓN EXTERNA.}

El complejo cúltico de la Rábita de Guardamar tiene desde hace tiempo una proyección nacional e internacional, si bien, bastante restringida al ámbito científico. Se ha dado a conocer a través de varias ponencias y comunicaciones presentadas en Congresos nacionales e internacionales de Arqueología Medieval; mediante la publicación de numerosos artículos y libros, toda vez que, ha sido expuesta profusamente en conferencias científicas y divulgativas impartidas a un variado público. Asímismo, es el tema de una exposición monográfica diseñada y montada por un equipo del Museo Arqueológico de Alicante, que fue cedida posteriormente a la Casa de Cultura de Guardamar del Segura, lugar en el que hoy puede visitarse. 
Esta línea de difusión proyectada hacia el exterior del Parque se mantendrá y potenciará en el futuro, ampliando su radio de acción. Las actividades en este sentido irán dirigidas no sólo al público inmerso en la investigación histórica, sino que abarcará un mayor segmento social. Para la consecución de este objetivo se diversificará la oferta con exposiciones itinerantes de distinto contenido y nivel científico: desde una visión global del Parque hasta monografías de temas concretos y puntuales.

Un complemento de apoyo imprescindible para la comprensión y disfrute del Parque son las publicaciones de los diferentes aspectos que este contempla. Estas publicaciones se pensarán para cubrir una amplia y variada demanda cultural. Se pondrá a disposición del público desde breves guías explicativas, que informen sobre las áreas y servicios del Parque y su aprovechamiento, hasta cuadernillos didácticos para grupos de escolares, pasando por catálogos más especializados. El Parque se preocupará, igualmente, de la publicación y difusión de las investigaciones generadas sobre cualquiera de los elementos y disciplinas que en él se estudian, ya que, la investigación no tiene razón de ser si no se divulgan sus resultados, si no se comparten $y$, en definitiva, si no se interrelacionan con otros.

\section{MUSEALIZACIÓN DEL PARQUE ARQUEOLÓGICO.}

La musealización de un conjunto complejo de elementos, de un Parque Arqueológico, no puede de ninguna forma improvisarse, debe responder a la combinación de un programa científico y de un proyecto museográfico.

El programa científico de un Parque Arqueológico, es decir, los objetivos y funciones que acabamos de definir en el apartado anterior, determinará el contenido y significado del hecho a exponer, será, por lo tanto, su soporte ideológico. Mientras que, el proyecto museográico entenderá de la organización espacial del Parque Arqueológico. El desarrollo de dicho proyecto, la estructura de la exposición, los itinerarios, etc... estarán en función de las directrices que marque el programa cientíico. De esta forma, el proyecto museográfico se convierte no sólo en fiel reflejo de los objetivos que el Parque persigue, sino que deviene un instrumento más en la consecución de los mismos.

Abordar la compleja labor de musealización del Parque Arqueológico de la Rábita requiere, evidentemente, la elaboración de un amplio "Proyecto museográfico". No obstante, sí conviene señalar los principios rectores que deben animar la musealización del Parque; los elementos materiales a musealizar; la infraestructura con la que éste debe dotarse y su ordenación espacial.

\section{III.I PRINCIPIOS RECTORES DE LA MUSEALIZA- CIÓN DEL PARQUE.}

El futuro proyecto museográfico deberá transmitir el contenido y el significado del hecho a comunicar, respondiendo tanto a las necesidades educativas como a las expectativas del público visitante. Mediante un mensaje, cuyo soporte será la exposición en sus distintas modalidades, el proyecto hará legible el discurso erudito de la investigación para que sea aprehensible a los usuarios del Parque.

\section{I. I. VARIEDAD EXPOSITIVA.}

La exposición de los distintos componentes del Parque Arqueológico deberá adaptarse al conjunto, al lugar, a los destinatarios y a las diversas coyunturas. Así, con la variedad expositiva se pretende cubrir distintas necesidades: una exposición temporal no responde a las mismas necesidades que una permanente, como tampoco la reconstrucción de un hecho in situ tiene el mismo significado que la presentación de los objetos en sala.

El Parque Arqueológico promoverá exposiciones permanentes, temporales e itinerantes. Entre las exposiciones permanentes son fundamentales aquellas en que los objetos- ambiente, muebles 0 inmuebles- se musealizan in situ y al aire libre. Este tipo de exposición "abierta" afectará al monumento en sí y al paraje natural que lo circunda. Otra modalidad de exposición permanente será la que presente los objetos en sala. Para ello el Parque deberá dotarse de una infraestructura que permita exponer sus componentes naturales y arqueológicos, en unas aulas de la naturaleza, en un pequeño museo de temática histórico-arqueológica y en salas de carácter general. Dicha infraestructura 
debe entenderse como instalaciones museográficas de apoyo a las exposiciones "abiertas" y, en ningún caso, como elementos disuasorios en la visita del Parque.

Por otra parte, las exposiciones temporales estarán sujetas a distintas coyunturas y necesidades intrínsecas o extrínsecas al Parque. Por ejemplo, la celebración de un acontecimiento cientíico, relacionado con las disciplinas de estudio que promueve el Parque, puede motivar el montaje de una exposición temporal sobre un tema convergente. Igualmente, la necesidad de difusión de un determinado estudio o elemento del Parque puede suscitar el diseño de una exposición de carácter temporal.

Por último, no debemos olvidar la importancia que las exposiciones itinerantes tienen a la hora de transmitir la imagen y contenidos del Parque fuera de sus límites físicos. Toda exposición itinerante, de carácter monográfico o no, deberá pensarse en relación al lugar donde debe ser expuesta, al público al que se dirige y al objetivo que pretende alcanzar.

\section{I.2. CONCEPCIÓN EXPOSITIVA.}

En el proyecto museográfico las diversas modalidades de exposición se caracterizarán, ante todo, por su dinamismo y versatilidad. Ambos caracteres incidirán sobre el contenido científico, el medio expositivo y los componentes de la exposición.

Es decir, el contenido científico variará en función de los conocimientos generados por la propia investigación. La exposición es el medio con el que el Parque comunica su realidad, por tanto, una exposición que no se adapte al estado de la investigación resultará, a la larga, obsoleta y no servirá a su principio fundamental. El proyecto museográfico, mediatizado desde todo punto por el programa u objetivos inherentes al Parque, deberá cuidar sobre todo la actualización de la exposición del mismo en sus distintas modalidades y versiones, ya que, es la forma en la que éste se materializa.

Por su parte, los medios expositivos deberán concebirse como módulos que permitan una continua renovación de la exposición, es decir, deberán ser capaces de adaptarse a los avances de la investigación y a las novedades que se produzcan en materia expositiva. La movilidad y versatilidad de los paneles, vitrinas, iluminación y, en definitiva, de todo el soporte expositivo debe estar garantizada, para con ello poder variar el diseño de las distintas muestras. Ahora bien, este soporte expositivo debe ser un instrumento discreto que facilite la comprensión del objeto y, en ningún caso, entorpezca y distorsione con su presencia la comunicación entre éste y el público que lo contempla.

Los diferentes tipos de exhibiciones precisarán de un soporte expositivo ajustado a sus características, dependiendo fundamentalmente de su lugar de ubicación: al aire libre o en sala. De otro lado, este soporte variará en función del tipo de componente expositivo que sustente -objetos muebles, textos, maquetas, planos, etc.... . No obstante, el Parque deberá tender a la uniformidad en el diseño y en los materiales del mismo; de forma que, transmita, en todo momento, una imagen equilibrada y distintiva.

Por último, será misión del proyecto museográfico la elección y tratamiento de los componentes expositivos que se presentarán en las diversas muestras. Lógicamente los componentes fundamentales en las distintas exposiciones serán los elementos muebles e inmuebles, exhumados en la excavación, y los elementos naturales que conforman el paraje del Parque. Si bien, no debemos olvidar que también son componentes expositivos necesarios los textos explicativos, ilustraciones, los medios audiovisuales, la señalización, etc...

En la concepción y diseño de las exposiciones se tenderá a conciliar el valor singular del objeto con el valor documental del mismo, buscando el equilibrio entre el objeto, cuya exposición le confiere una valía sin par, y la multiplicidad de significados contenidos en él, en su relación con otros objetos y documentos. Ya que, con frecuencia, la brillantez que rodea al objeto en su exposición oscurece su verdadero valor contextual, funcional e histórico. Los objetos exponibles serán considerados como elementos de diferentes conjuntos; deben, individualmente o en su relación con los demás, comunicar su significación, es decir, contarnos una historia.

En la transmisión de esta historia la exposición del Parque se enriquecerá con una apoyatura gráfica y textual. Desde que el visitante entra en el Parque se le facilitará la elección del itinerario a 
seguir o de la muestra a visitar, a través de una información gráfica introductoria, ya sea un panel, una breve guía-plano o un audiovisual, que le indique las diversas alternativas que el Parque ofrece.

Mediante planos generales y planos detallados de los diferentes espacios de exposición, instalados estratégicamente, el visitante será en todo momento consciente del lugar del Parque donde se encuentra y, por ende, del área, edificio o elemento que visualiza. Este primer nivel de información sobre la distribución espacial del Parque se verá reforzado con los títulos de cada una de las unidades de presentación y con breves textos e ilustraciones. Estos ayudarán a comprender el significado de cada elemento como un hecho individual y en su relación con el resto.

Estos breves textos explicativos y el material gráfico que les acompañe -planos, axonometrías, reconstrucciones, etc...- deberán realizarse con una cualificación científica, es decir, se basarán en los diferentes estudios desarrollados en el Parque. No obstante, serán tratados por especialistas, dinamizadores culturales, pedagogos, etc..., que hagan legible su contenido, para que el mensaje llegue a la mayoría del público visitante.

Esta primera información básica se enriquecerá, para aquellos usuarios que muestren un mayor interés por alguno de los temas expuestos en el Parque, con una segunda serie de textos y apoyatura gráfica, cuya comprensión precisa de una atención suplementaria. Con ello se tratará de cubrir las exigencias de un público más aleccionado, diversificando la oferta cultural del Parque.

\section{III.2. COMPONENTES MATERIALES A MUSEALI- ZAR.}

El Parque Arqueológico de la Rábita ha sido concebido desde el principio como una realidad museística de gran complejidad, dada la diversidad de elementos que en él confluyen. Los dos grandes espacios museables y caracterizadores del Parque son el paraje natural -el ecosistema de dunas litorales- y el yacimiento arqueológico -la Rábita califal-. Ambos poseen múltiples y variados contenidos cuya adecuada presentación requerirá la utilización de medios expositivos diversos y específicos.

\section{III.2. I.PARAJE NATURAL.}

Un componente innovador $y$, a la vez, definidor de esta concepción museográfica, del Parque Arqueológico, es el medio natural donde se integra. Este paraje natural sin el cual no tiene sentido el Parque deberá, sin embargo, mantener una relación armónica con el conjunto de los componentes del mismo y, fundamentalmente, con el monumento arqueológico.

No es necesario repetir que el paisaje actual del Parque deberá estructurarse de manera que se consiga un entorno atrayente. La conjunción del paraje natural y de los itinerarios proyectados en el interior del Parque tenderá a ensalzar la singularidad y monumentalidad del bien arqueológico. El medio natural presenta un claro contraste cromático respecto al monumento arqueológico, se convierte, por lo tanto, en el elemento ideal para la definición del espacio, indicando las pausas o descansos en la visita y marcando itinerarios representativos. Por consiguiente, será labor fundamental del Parque conservar y proteger dicho entorno, potenciando su regeneración e idónea utilización.

No obstante, será igualmente misión del Parque intentar restituir o recrear, en una zona del mismo que presente las condiciones óptimas para ello, un paisaje que se acerque lo más fielmente posible al ambiente original en el que transcurrió la vida de la Rábita, reconstruyendo la imagen perdida.

La musealización del medio natural preveerá el diseño de unos recorridos de temática medioambiental en el área delimitada por el Parque y en sus inmediaciones. Estos deberán concebirse como circuitos de carácter didáctico que potencien la comprensión del ecosistema actual y del paleoambiental.

Un elemento de apoyo a esta comprensión serán las aulas de natura, cuya creación deberá contemplarse en el futuro proyecto museográfico, entendiéndolas, fundamentalmente, como aulas experimentales y de información complementaria a la visita.

\section{III.2.2. RESTOS ARQUEOLÓGICOS.}

Abordar la musealización de unos restos 
arqueológicos in situ requiere un previo y profundo conocimiento de cada uno de los elementos que lo componen, de su importancia y de su significación dentro del conjunto. Cada elemento, analizado individualmente, debe ser capaz de resaltar un valor concreto de ese conjunto, toda vez que, en su interacción, explicar el hecho histórico que aquellos transmiten.

El complejo cúltico de la Rábita se resuelve con un variado entramado constructivo, en el que destacan algunas de sus edificaciones, no tanto por ser obras de singular fábrica sino por el carácter emblemático que poseen. Nos estamos refiriendo a aquellas construcciones cuya presencia distingue al monumento, sin las cuales no estaríamos ante una rábita islámica. Es, por lo tanto, sobre estos elementos sobre los que el proyecto museográfico deberá incidir, subrayando su simbología. Sólo así se podrá transmitir de manera comprensible el verdadero significado de una rábita: lo que es y lo que supone dentro de un territorio concreto y dentro de una determinada cultura.

En conclusión, si una rábita islámica es un bastión del islám para la aculturación y defensa de un territorio y se define por su temple religioso-cenobítico y por su condición militar, será necesario resaltar aquellos elementos que referencien ambos valores.

\section{III.3. INFRAESTRUCTURA Y PROPUESTA DE ORDENACIÓN ESPACIAL.}

Como ya venimos apuntando en apartados anteriores los dos grandes espacios de exposición al aire libre -el paraje natural, el yacimiento y sus respectivos itinerarios- se verán reforzados con unas instalaciones museísticas de apoyo: dos pequeñas aulas de natura, la recreación del área sacra de la Rábita y salas de exposición complementaria. Estas instalaciones deberán concebirse como puntos de introducción y de información complementaria a la visita. El Parque precisa, asímismo, de un soporte infraestructural de servicios tales como: un área de acogida, aparcamientos, edificio plurifuncional, etc... La propuesta de ordenación espacial de esta compleja infraestructura fue elaborada por el arquitecto Mariùs Bevià de la forma que sigue:

\section{I. ÁREA DE ACOGIDA.}

Se sitúa en el extremo del área de protección junto a la desembocadura del río Segura, donde se plantea un edificio plurifuncional con las siguientes funciones: oficina de recepción y orientación, gabinete didáctico, tiendas de souvenirs, bar-restaurante, servicios, pequeño dispensario de emergencias, puesto de policía municipal y almacenes. En este edificio se ubicarían igualmente las salas de exposición complementaria. La complejidad expositiva del Parque Arqueológico de Guardamar precisará de unas instalaciones museísticas de carácter general que permitan introducir al visitante en su realidad material, facilitando una satisfactoria visita, una adecuada comprensión y un óptimo disfrute. Las muestras de estas salas además de transmitir un conocimiento de la cultura andalusí en general, que capacite al usuario para entender el lugar y la importancia que una institución como la Rábita ocupó dentro de esta cultura y de su relación con el territorio que defendía y aculturaba, tratará de dar a conocer toda una serie de hechos significativos referentes al Parque: métodos arqueológicos, procesos de restauración, sistemas de restitución y regeneración medio-ambiental, etc...

La zona circundante al área de acogidas se ajardinará recreando un ambiente adecuado y diferenciado de la pinada.

\section{RECONSTRUCCIÓN ÁREA SACRA.}

Se sitúa en las proximidades del área de acogida sobre una duna que refleje el paleoambiente de la época. Sobre ella se realizará una reconstrucción ideal a escala del área sacra de la Rábita. La importancia que el área sacra posee para la comprensión de la Rábita y, en general, de las creencias religiosas del Islam, unido a la dificultad de transmitir toda esta información en el monumento original, sin distorsionarlo, aconseja su recreación fuera de los límites del yacimiento. De esta forma, la reconstrucción del área sacra podrá contener el soporte informativo -textos, planimetrías, maquetas, etc...- que se le niega en el yacimiento, funcionando, a su vez, como pequeña instalación museal. Su valor expositivo reside en la introducción del visitante en la compleja realidad que, posteriormente, podrá contemplar difuminada en el original. Con esta reconstrucción 
se pretende restituir y mostrar al usuario el volumen real que debieron tener los edificios, recrear sus técnicas constructivas y decorativas y, por ende, su ambiente primigenio.

\section{AULAS DE NATURALEZA.}

Se ubicarán en el interior de la pinada con acceso desde las sendas peatonales $y$, una de ellas, también desde el camino asfaltado, propiciando distintos itinerarios. Las aulas dedicadas a la naturaleza deberán tener sobre todo un carácter experimental. En ellas se realizarán pruebas de laboratorio, análisis con microscopios, etc..., en definitiva, serán pequeños museos en los que el usuario participe activamente, pueda manipular y experimentar con los componentes naturales. Se concebirán también como una exposición que explique el ecosistema de dunas litorales $y$, a través de textos y material fotográfico antiguo, las mutaciones que éste ha sufrido hasta llegar a su estado actual.

\section{YACIMIENTO.}

Se adecuará la visita del área excavada mediante recorridos controlados internos que posibiliten el conocimiento de la Rábita, al mismo tiempo que la protegen. Este espacio se complementaría con elementos muebles y torre panorámica para contemplar el conjunto de las dunas y el entorno físico que las rodea.

\section{5. ÁREAS DE ESPARCIMIENTO.}

Se ubican estas dos áreas donde ya existen, la zona de la Fonteta y la de Merenderos, potenciándolas de manera que puedan ser usadas complementariamente a la visita.

\section{ITINERARIOS.}

El área del futuro Parque se organiza en varios itinerarios peatonales o rodados, entrelazados entre sí, aprovechando en parte las sendas y los dos caminos existentes.

\section{EDIFICIO PLURIFUNCIONAL.}

Se sitúa en una duna en la zona más cercana al pueblo y con una funcionalidad destinada a la investigación científica, disponiendo de una pequeña zona de aparcamiento. En él se plantean las siguientes actividades: dormitorios, comedores, despachos de administración y gestión, aulas y talleres de conservación, sala multiuso, biblioteca, laboratorios y almacenes.

Todo lo anteriormente expuesto queda recogido en el Plano "Propuesta de Ordenación del Estudio".

\section{NOTAS}

I El equipo, coordinado por Rafael Azuar director del proyecto del Parque Arqueológico de la Rábita de Guardamar, estaba formado por las arqueólogas Marga Borrego y Rosa Saranova, que realizaron el estudio museológico; por el arquitecto Mariùs Bevià, responsable de la propuesta de ordenación formal y legal del estudio; y por el dinamizador cultural Mario Castro, autor del estudio de dinamización.

2 Junto a la Rábita de Guardamar se incluyeron en este "Plan Experimental" seis yacimientos: el Monasterio visigodo de Santa María de Melque (Toledo), la Cueva Pintada de Galdar (Gran Canaria), la Necrópolis púnica de Puig dels Molins (Ibiza), la Villa romana de Els Munts (Altafulla-Tarragona), la Zona Arqueológica Protohistórica de Campa Torres (Asturias) y la Villa romana de Carrenque (Toledo). Todos estos sitios arqueológicos se encuentran actualmente en fase de definición.

3 En el interesante trabajo Estudio sobre el medio y la biocenosis en los arenales costeros de la Provincia de Alicante de A. ESCARRÉ y otros autores se analiza detenidamente el origen y la problemática del paisaje dunar y sus sistemas ecológicos.

\section{BIBLIOGRAFÍA}

ALVA BALDERRAMA, A.; CHIARI, G. (1987): "Protección y conservación de estructuras excavadas de adobe", La conservación en excavaciones arqueológicas, ICCROM. Madrid, pp. I |3-123.

ATKINSON, F. (197I): "Les noveaux musées de plein air", Museum, XXIII, nº 2. París, pp. 103-107. 
AZUAR RUÍZ, R. (1985): "Primera noticia de los trabajos arqueológicos realizados en el yacimiento islámico de las Dunas de Guardamar del Segura (Alicante). Una posible Rábita de época califal", Sharq Al-Andalus, vol. 2. Alicante, pp. 125-I36.

AZUAR RUÍZ, R. (1986): "Dunas de Guardamar", Arqueología en Alicante 1976- 1986. Alicante, pp. I53-I54.

AZUAR RUÍZ, R. (1986a): "Una rábita califal en las Dunas de Guardamar (Alicante)", I Congreso de Arqueología Medieval Española, Vol. III. Zaragoza, pp. 505-520.

AZUAR RUIZZ, R. (1987): "El posible Al-Monastir de las Dunas de Guardamar del Segura (Alicante)", Les Illes Orientals D'al-Andalus. Palma de Mallorca, pp. 265-309.

AZUAR RUÍZ, R. (1987a): "La Rábita de Guardamar. Mil anys sota les Dunes", Debats, Vol. 21. Valencia, p. 14.

AZUAR RUÍZ, R. (1988): "La época islámica”, Historia del Pueblo Valenciano, Vol. 9. Valencia, pp. 161-180.

AZUAR RUÍZ, R. (1989): "El conjunto religioso del ribat de las Dunas de Guardamar (Alicante)", Archivo de Prehistoria Levantina, Vol. 19. Valencia, pp. 375-384.

AZUAR RUÍZ, R. (1990): "Una rábita hispano-musulmana del siglo X (Guardamar del Segura, Alicante, España)", Archeologique Islamique, Vol. I. París, I09-122.

AZUAR RUÍZ. et alii (1989): La rábita califal de las Dunas de Guardamar (Alicante): Cerámica, Epigrafía, Fauna, Malacofauna. Alicante.

AZUAR, R.; BEVIA, M.; BORREGO, M.; SARANOVA, R. (|99|): "La Rábita de Guardamar (Alicante): su arquitectura", Cuadernos de Madinat al-Zahra, Vol. 2. Córdoba, pp. 55-83.

AZUAR, R; BEVIA, M. (en prensa): "La Rábita Califal de Guardamar del Segura (Alicante). ¿Un Parque Arqueológico?", Seminario de Parques Arqueológicos, (Madrid, Diciembre 1989). Madrid.

AZUAR, R.; BEVIA, M.; BORREGO, M.; SARANOVA, R. (en prensa): La arquitectura de la Rábita Califal de Guardamar del Segura.

BARRERA, A. (1972): "Le Musée d'historie naturelle de la ville de Mexico: sa structure et ses fonctions", Museum, XXIV, n4. París, pp. 208-2I8.

BIRO, F. (1972): "Protection des monuments d'architecture traditionelle et musées d'etnographie de plein en Hungrie", Museum, XXIV, nº 4. París, pp. 208-217.
CABALLERO ZOREDA, L. (1982): Funciones, organización y servicios de un Museo: el Museo Arqueológico Nacional de Madrid. Guadalajara.

CABALLERO ZOREDA, L.: "El Parque Arqueológico. Un sistema de gestión del patrimonio". (Copia mecanografiada).

CABALLERO, L.; LATORRE, P.; VEAS, N.: (1988): "Arqueología y Yacimiento frente a Intervención Integrada y Sitio Histórico. El proyecto de Parque Arqueológico en el Sitio Histórico de Melque (Toledo)", I Congreso de Arqueología de la Provincia de Toledo. Toledo, pp. 373-405.

CABAlLERO, L.; LATORRE, P.; ANDREU, J.; 1988: "Hipótesis para un segundo plan de intervención en la iglesia y el yacimiento arqueológico de Santa María de Melque (provincia de Toledo)", I Congreso de Historia de Castilla-La Mancha. (Ciudad Real 1985), Vol. IV. Ciudad Real, pp. 313-320.

CABALLERO ZOREDA, L. et alii; "El Parque del "Sitio Histórico" de Melque (Toledo)". (Copia mecanografiada).

CABALLERO CARO, P. (1988): "Algunas consideraciones sobre la Didáctica y los Museos Antropológicos", IV Jomadas de departamentos de educación y acción cultural de museos. Madrid, pp. 50-53.

CAMPOS CARRASCO, J.M. et alii (1980): "Museo y pedagogía. Proyecto de un "taller para los niños" en el Museo Arqueológico de Sevilla", Museos. Madrid, pp. 122-126.

COCA PAYERAS, M. (1990): "Patrimoni cultural, bens culturals i tècniques de protecció (trets generals de la seva normativa)", Bolletí de la Societat Arquelògica Lul.liana, Vol. 46. Palma de Mallorca, pp. 49-59.

DAGOGNET, F. (1984): Le musée sans fin. Seyssel.

D'AMATO, T. (199I): "Elementi per l'arredo del Parco archeologico di Selinunte", Sicilia Archeologica, Vol. XXIV, n75. pp. 3।-45.

DELARGE, A. (1991): "Un pulmón en las puertas de París", Parques y Jardines de las delicias. Museum, n 169. París, pp. 25-29.

DELOCHE, B. (1985): Museologica. Contradictions et logique du musée. París.

DE VARINE-BOHAN, H. (1973): “Un musée 'éclaté': le Musée de l'homme et de l'industrie", Museum, Vol. XXV, n4. París, pp. 242-249. 
DE VARINE-BOHAN, H. (1976): "Le musée moderne: conditions et problèmes d'une rénovation", Museum, Vol. XXVIII, n³. París, pp. 126-139.

DE VARINE-BOHAN, H. (1977): "El museu al servei de l'home i del desenvolupament", Artitugi, n 6. Barcelona, pp. 3-7.

DUCLOS, J.C. (1980): "Musée camargais, mas du Pontde-Rousty, Arles, France", Museum, Vol. XXXII, nI/2. París, 24-33.

ENNABLI, A. (1990): "Pour la creation d'un parc archeologique a Carthage-Tunisie", Cedac Cartage, Bulletín II. Cartago, | -5.

ESCARRE, A.; MARTIN, J.; SEVA, E. (1989): Estudio sobre el medio y la biocenosis en los arenales costeros de la Provincia de Alicante. Instituto Juan Gil-Albert. Alicante.

EVRARD, M. (1980): "El Ecomuseo de Le CreusotMontceau-Les- Mines: balance de diez años de actividad"', Museum, Vol. XXXIl, n4. París, pp. 230-238.

FARRO, A. (1985): Museus d'Història. Propostes per a un programa. Barcelona.

FERNANDEZ MIRANDA, M. (198I): "Arqueología y legislación”, Caesaraugusta, n 53-54. Zaragoza, pp. 39-58.

FRIEDLÄNDER, R. (1976): "Découverte du musée par la création”, Museum, Vol. XXVIII, nº. París, pp. 14-27.

FULLEA, F.; RIBAO, D. (1988): "Aplicaciones didácticas de los museos en los programas de la reforma de E.G.B. Experiencias escolares en los Museos", IV Jornadas de departamentos de educación y acción cultural de museos. Madrid, pp. 56-61.

GARCÍA, A. A. (1986): "La investigaciò de l'educador de Museus". Conferencia ICOM-CECA a Barcelona. Revista de Museos. Barcelona, pp. 49-5I.

GARCÍA BLANCO, A. (1985): "Museo y educación: la visita escolar", Análisis e investigaciones culturales, Vol. 22. Madrid, pp. 62-80.

GARCÍA GIL, A. (1972): "La protección del patrimonio cultural y del patrimonio natural", Bellas Artes 72. Madrid, pp. 8-19.

GARCÍA INIESTA, N.; OLIVER SUNYER, G. (1990): "Preàmbul per a la qualitat de l'intervenció arquitectònica en el Patrimoni Històric", Bolletí de la Societat Arqueològica
Lulliana, Vol. 46. Palma de Mallorca, pp. I23-I 30.

GESTIN, S.P. (1983): "Le musée, expression d'un territoire", Quels musées pour quelles fins aujourd'hui?, Séminaire de l'Ecole du Louvre. París, pp. 187-194.

GIANFRANCESCHI VETTORI, I. (1978): Museo scuola città. Brescia.

GIRARD VILLEMURE, M. (1980): "Les forges du SaintMaurice, Trois-Rivières, Québec, Canadá"', Museum, Vol. XXXII, nI/2. París, pp. 34-42.

GÓMEZ, C. et alii ( 1985): "El museo por dentro. Experiencia didáctica realizada por escolares", Boletín Homenaje a Antonio Beltrán, n4. Museo de Zaragoza. Zaragoza, pp. 329-333.

GÓMEZ GONZALEZ, J. et alii (1980): “Aplicación de los medios audiovisuales a la función pedagógica del Museo Arqueológico de Sevilla", Museos. Madrid, pp. 127-132.

GUTIERREZ LLORET, S. (1986): "Cerámicas comunes altomedievales: contribución al estudio del tránsito de la Antigüedad al mundo paleoislámico en las comarcas meridionales del País Valenciano", Lucentum Vol. 5. Alicante, pp. 147-167.

GUTIERREZ LLORET, S. (1987): "Cerámicas comunes islámicas de las comarcas meridionales de Alicante (siglos VIII-X): avance de una tipología", Boletín de Arqueología Medieval, Vol. I. Madrid, pp. 7-23.

GUTIERREZ LLORET, S. (1987a): "Avance para una tipología de las formas modeladas a mano del Ribat Califal de Guardamar del Segura (Alicante)", II Congreso de Arqueología Medieval Española, Vol. II. Madrid, pp. 689704.

GUTIERREZ LLORET, S. (1988): Cerámica común paleoandalusí del Sur de Alicante (Siglos VIII-X). Alicante.

GUTIERREZ LLORET, S. (1990): "Espacio y poblamiento paleoandalusí en el Sur de Alicante: origen y distribución", III Congreso de Arqueología Medieval Española. Oviedo, pp. 34I-348.

HEINONFEN, R. (1959): "Regional and local Museums of the History of the Finnish Culture", Museum, Vol. XII, nI. París, pp. 40- 41.

INGVALDSEN, A.H. (1978): "Proposition pour un musée de la Lande, Norvège", Museum, Vol. XXX, n². París, 94-102. 
JELINEK, J. (1975): "Musée moderne, musée vivant", Museum, Vol. XXVIII, n². París, pp. 52-58.

LATORRE GONZÁLEZ-MORO, P. (1988): "El Sitio Histórico de Melque (prov. Toledo). La intervención integrada con una finalidad didáctica", Archeologia e Restauro dei Monumenti, I Ciclo di lezioni sulla ricerca applicata in Archeologia (Siena, 1987). Florencia, pp. 157-194.

LÓPEZ ÁLVAREZ, A.M. (1988): "Actividades didácticas del Museo Sefardí de Toledo", IV Jomadas de departamentos de educación y acción cultural de Museos. Madrid, pp. 82-87.

MARIANI, L. (1986): 'II 'Parco Archeologico' negli Stati Uniti d'America", Bolletino D'arte, Vol.35 y 36. pp. I7|- 778.

MARÍN, M. (1989): "La vida en los Ribat de Ifriquiya" en AZUAR et alii: La Rábita Califal..., Alicante, pp. 199-205.

MARTÍNEZ LATRE, C:; VELILLA CALAFELL, E. (1986): "Il curso sobre utilización didáctica del Museo. Sección arqueológica", Boletín homenaje a Antonio Beltrán, n5, Museo de Zaragoza. Zaragoza, pp. 475-479.

MONIOT, F. (1973): “L'Ecomusée de Marguèse, Sabres, dans le cadre du Parc naturel régional de Landes de Gascogne", Museum, Vol. XXV, nI/2. París, pp. 79-84.

MONTANER, J.M.; OLIVERAS, J. (1986): Los museos de la última generación. Barcelona.

MORA, P. (1987): "Conservación de revoques, estucos y mosaicos excavados". La conservación en excavaciones arqueológicas, ICCROM. Madrid, I03-I I2.

NEGRI, A. et alii (1983): /l Museo Cittadino: formazione, gestione, strutture. Roma.

PIERDOMINICI, Ma C; TIBALLI, M. (1986): "Il parco archeologico: analisi di una problematica", Bolletino d'arte 35 y $36,135-170$.

PY, M. et alii (|99|): LATTARA: Système d'enregistrement, de gestion et d'exploitation de la documentation issue des fouilles de Lattes. Mélanges d'histoire et d'archeologie de Lattes. Lattes.

QUEROL, Ma A. (en prensa): "El Parque Arqueológico: Definición y Filosofía", TABONA. Canarias.

RASMUSSEN (1960): "Les musées municipaux d'Odense", Museum, Vol. XIII, n². París, pp. 70-8I.
RINTERSBACHER (1952): "Un musée d'ecologie et d'histoire Niederösterlichisches Landesmuseum, Vienne", Museum, Vol. V, n³. París, pp. I78-186.

RIVIERE, G.H. (1985): "Definición evolutiva del ecomuseo", Museum, Vol. I48. París, p. I82-183.

RIVIERE, G.H. et alii (1989): La Muséologie selon Georges Henri Rivière. París.

SAHLBERG, I (1959): "Turun Kaupungin historiallinen Museo", Museum, Vol. Xll, nI. París, pp. 4I-46.

STANLEY PRICE, N. (1987): "La conservación en excavaciones y la recomendación de la Unesco de 1956", La conservación en excavaciones arqueológicas, ICCROM. Madrid, pp. |49-| 55.

STUBBS, J.H. (1987): "Protección y exhibición de estructuras excavadas", La conservación en excavaciones arqueológicas, ICCROM. Madrid, pp. 85-101.

TARRATS BOU, F. (1986): "Tarragona, museus i territori", FORUM, Tarragona.

TOUCET, P.; 1972: "Le Musée de Niamey et son environnement", Museum, Vol. XXIV, n4. París, pp. 204-207.

VALLEJO TRIANO, A. (|99|): "Crónica años 19881990", Cuademos de Madinat al-Zahra, Vol. 2. Córdoba, pp. | 83-222.

VEILLARD, J.V. (1972): "Problèmes du musée d'histoire à partir de l'éxpérience du Musée de Bretagne, Rennes", Museum, Vol. XXIV, n4. París, pp. 192-203.

VERDE CASANOVA, A. (1988): "La didáctica en el museo Antropológico", IV Jornadas de departamentos de educación y acción cultural de museos. Madrid, pp. 42-47.

W.AA. (1988): I siti Archeologici. Un problema di musealizzazione all'aperto. Roma.

W.AA. (1990): Jomadas sobre Parques con Arte Rupestre. Zaragoza.

W.AA. (1973): Musées, imagination et éducation. París.

WEYNS, J. (1959): "BOKRIJK: Premier musée de plein air de la Belgique", Museum, Vol. Xll, nI. París, pp. 2022. 


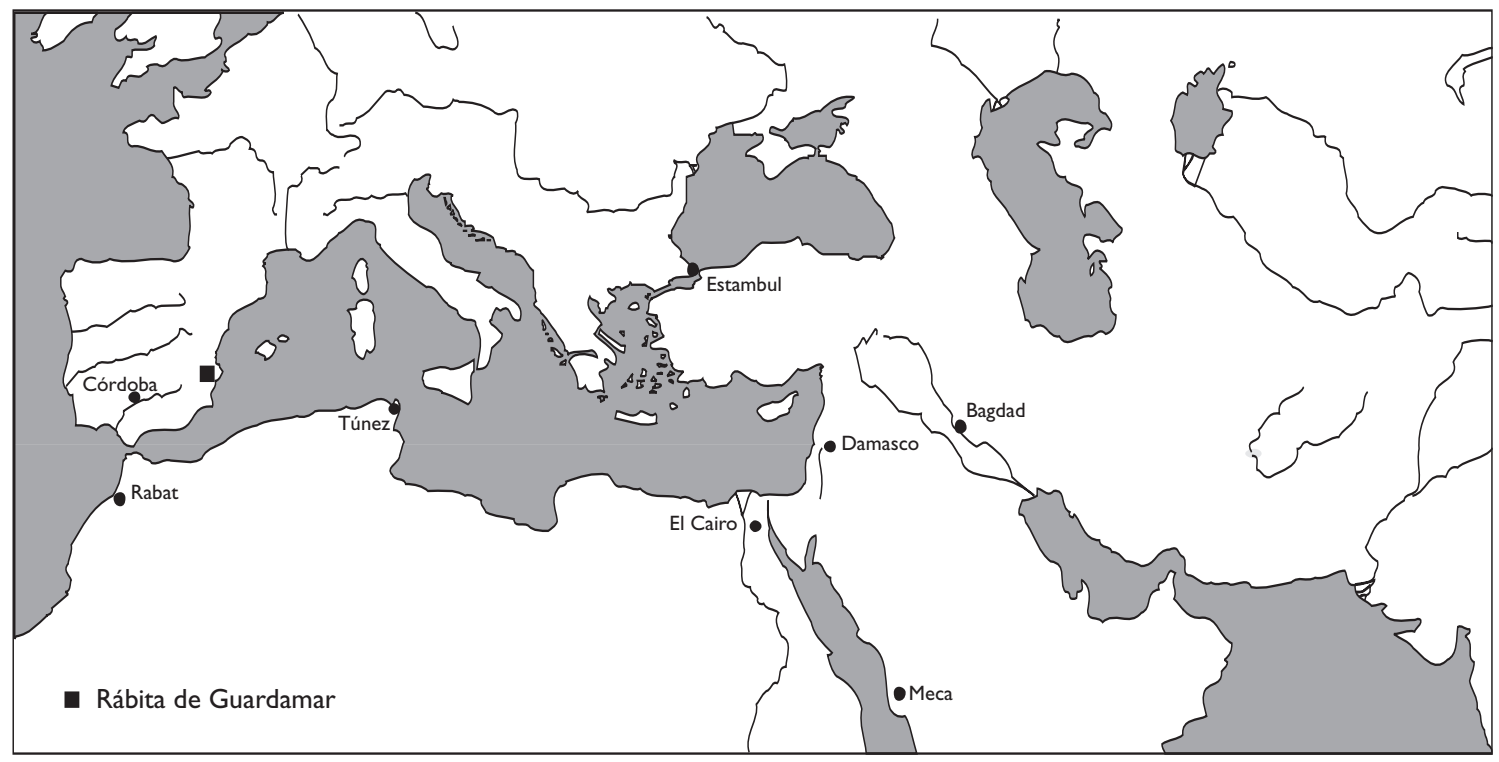

Rábita de Guardamar. Plano de situación

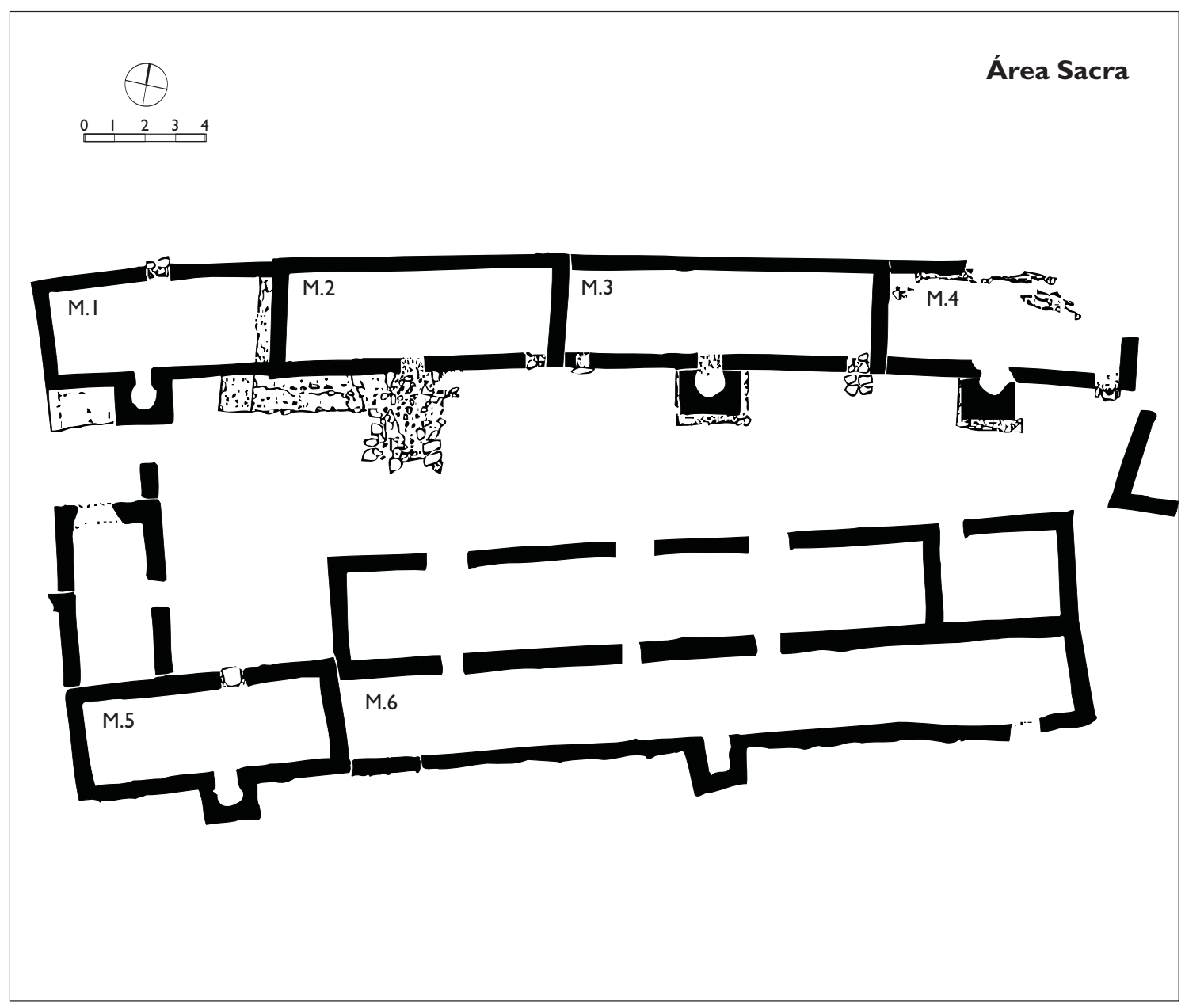

Rábita de Guardamar. Planta del Área Sacra 


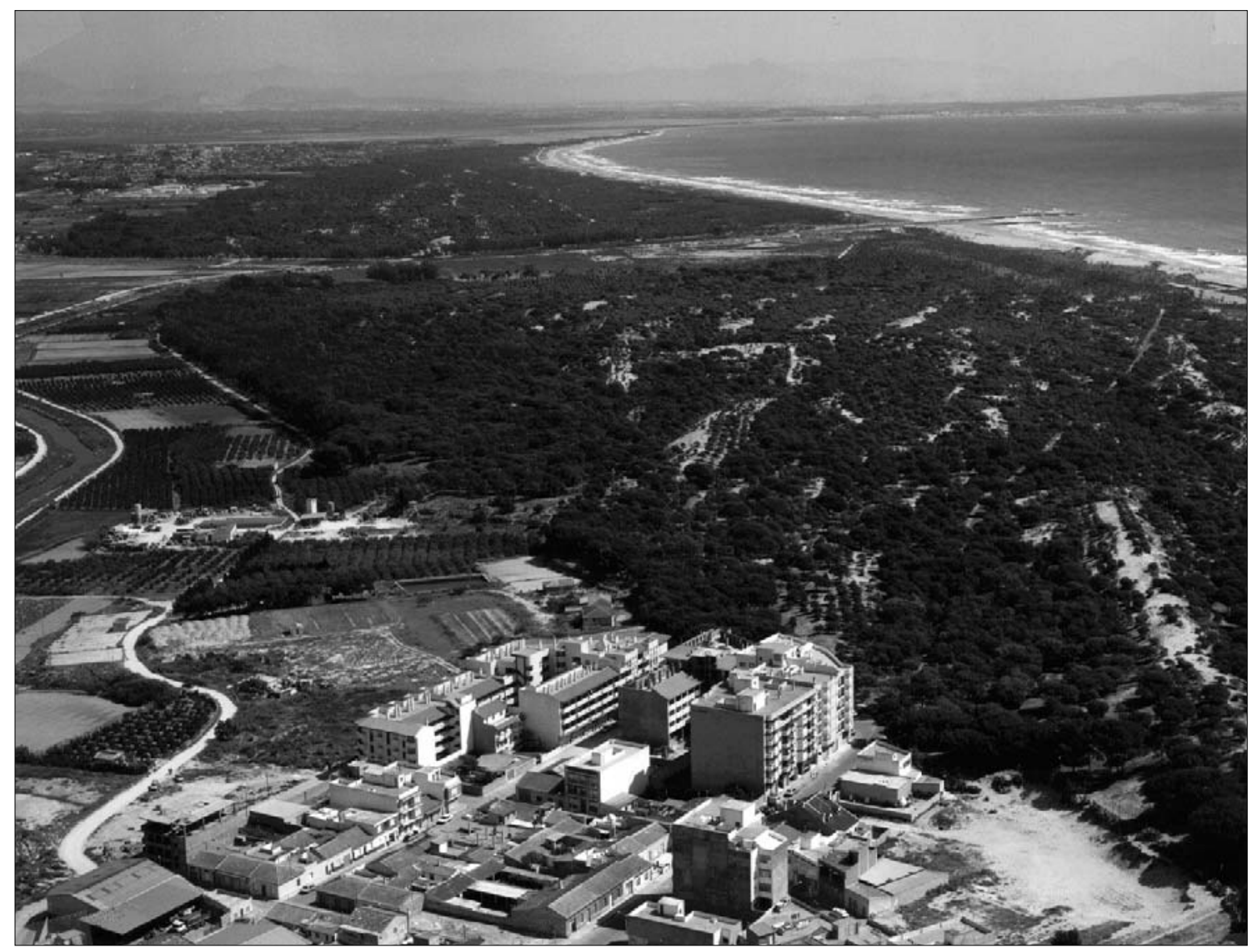

Fig. I. Vista aérea de la superficie del B.I.C. desde mediodía

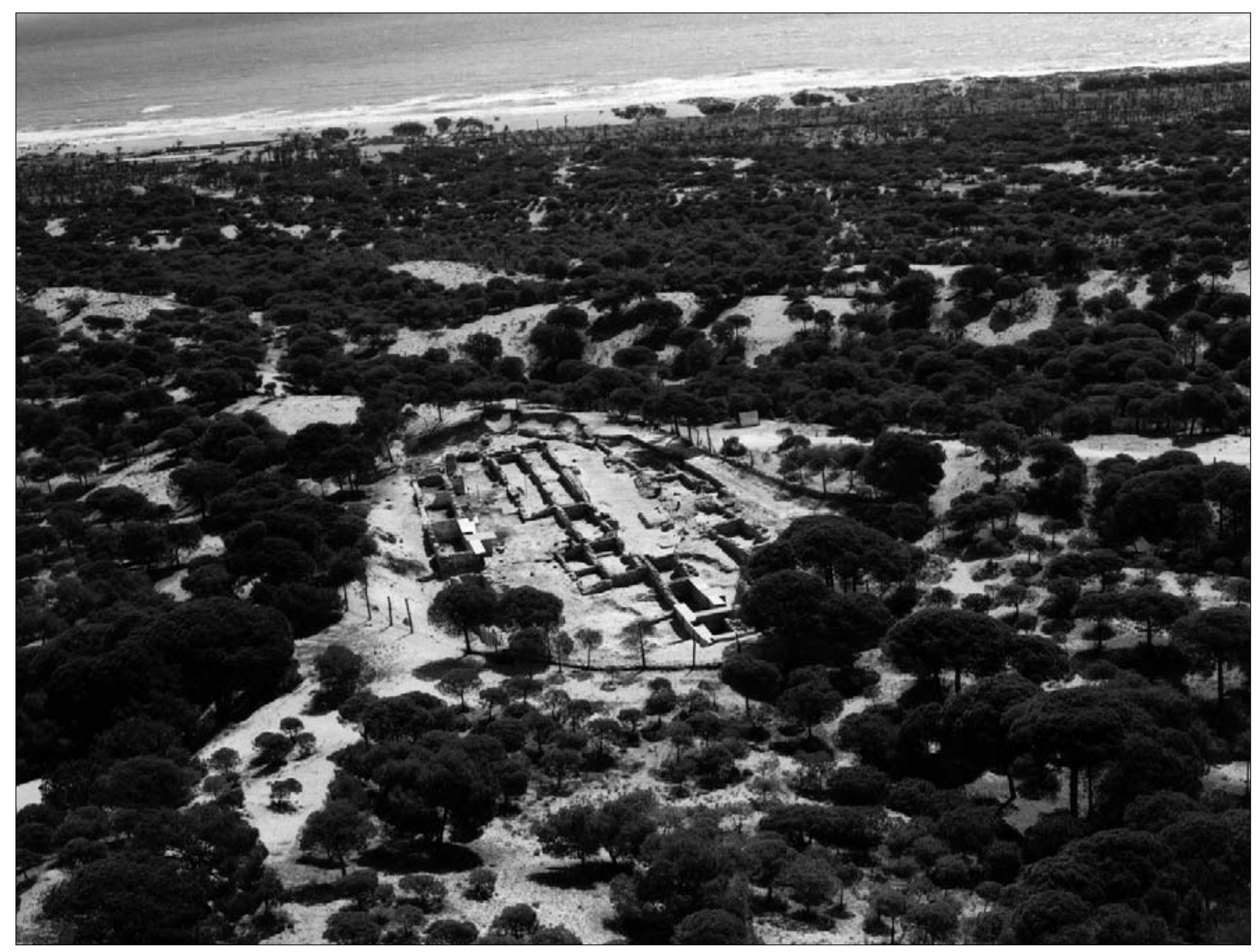

Fig. 2. Rábita de Guardamar. Vista aérea 


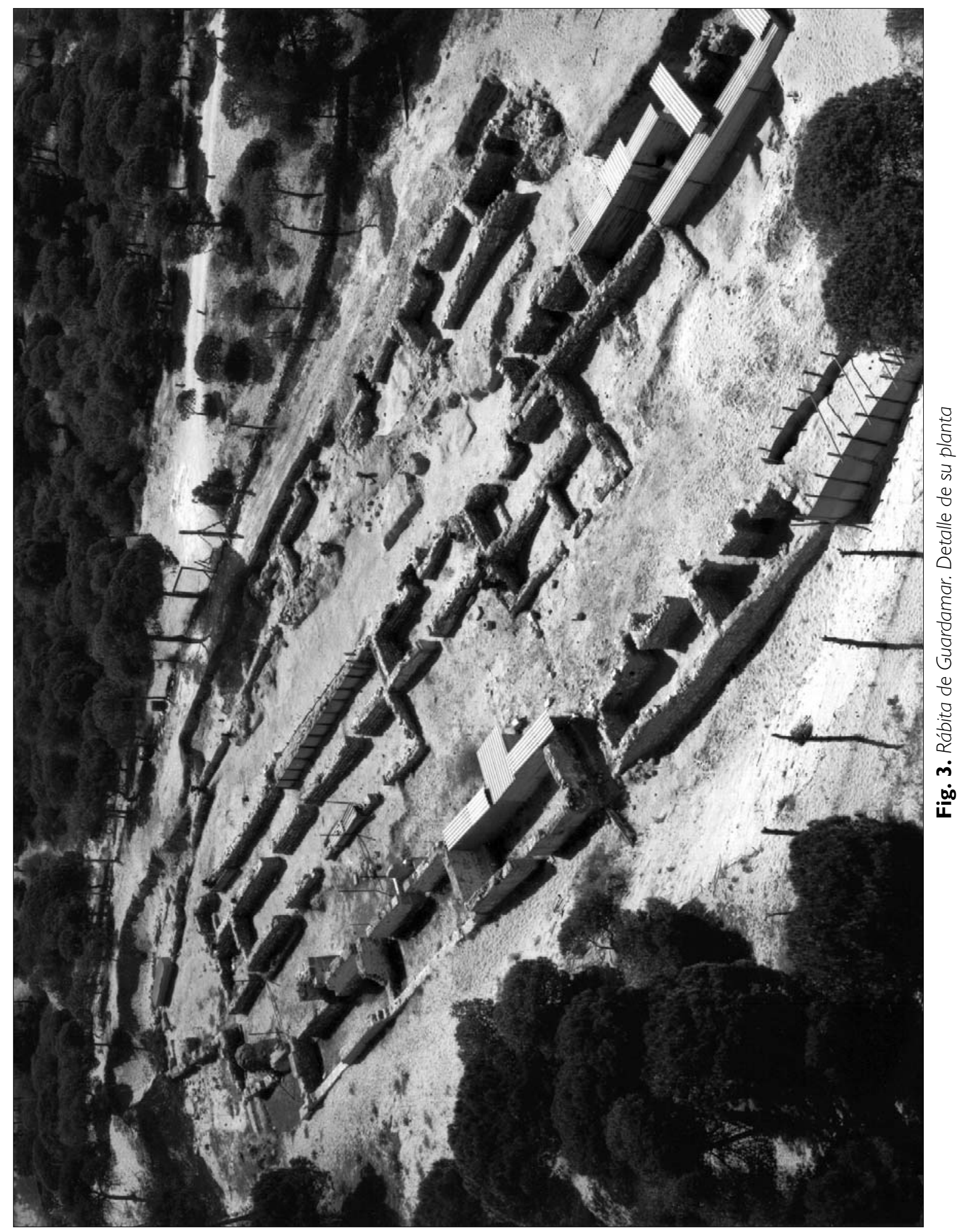




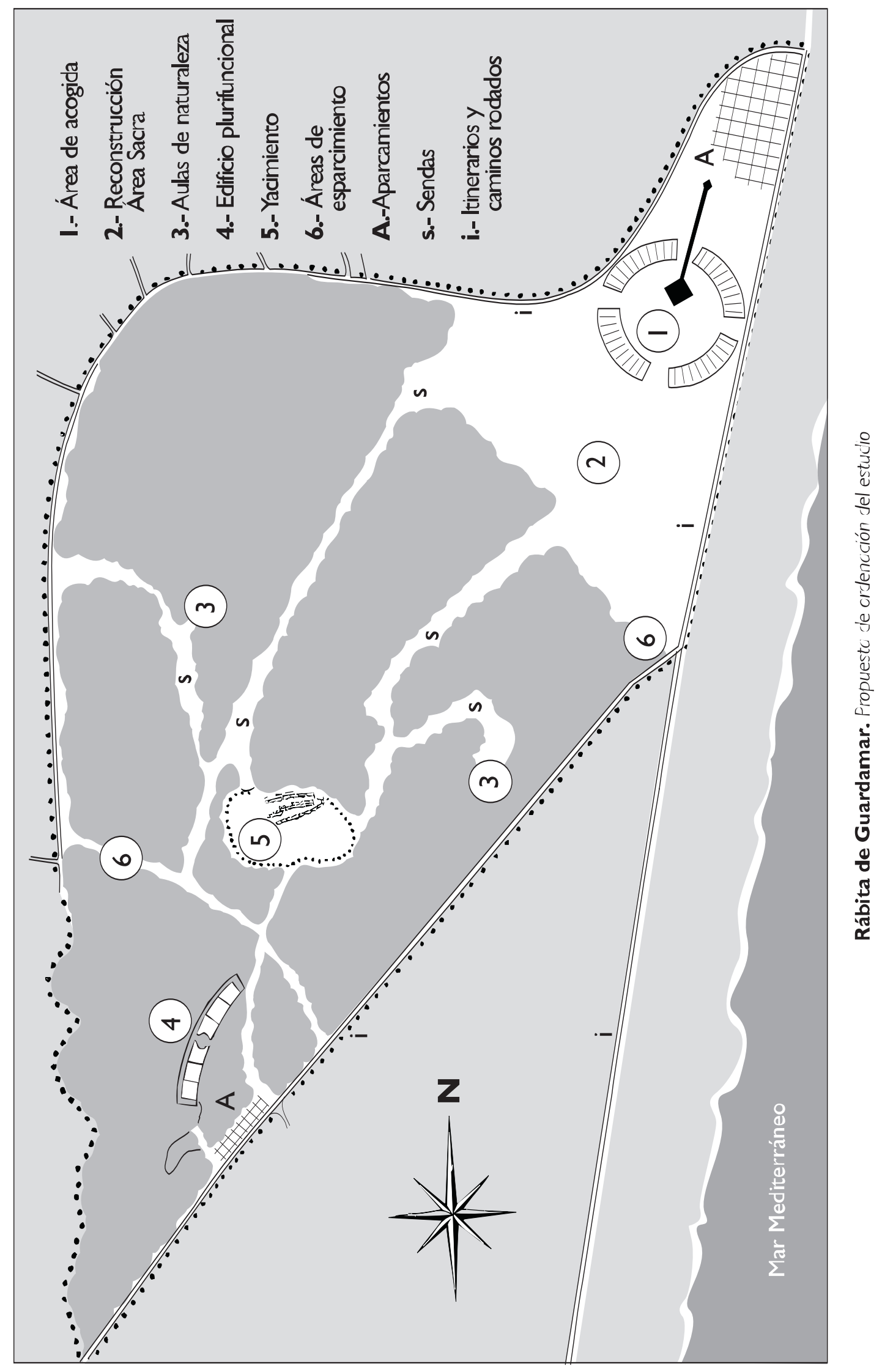



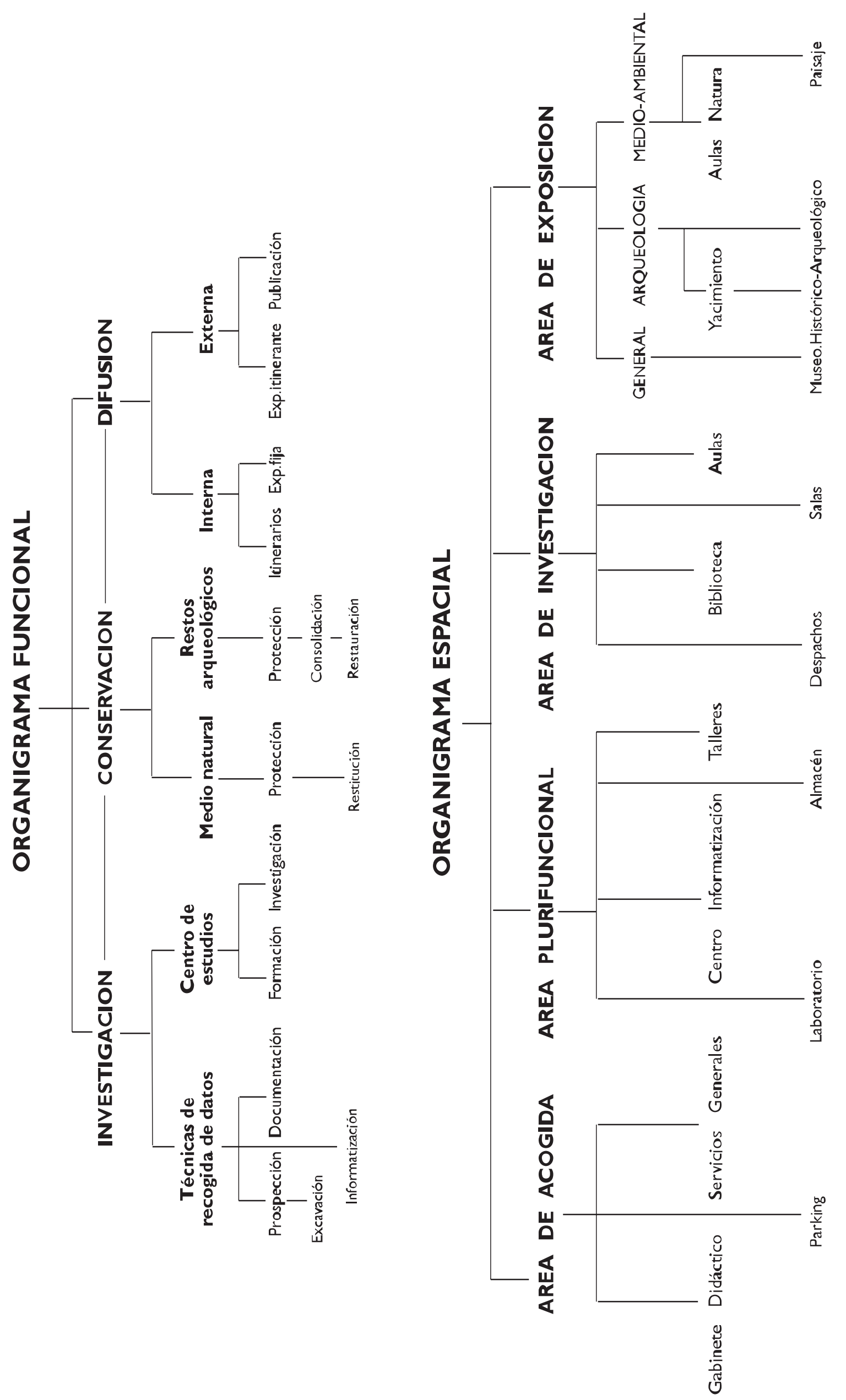